\title{
Comments on the Correlation between Morphology and Stress-Strain Properties of Styrene-Isoprene-Styrene Copolymer
}

\author{
Irena DANIEwSKA* and Claude PICOT \\ CNRS, Centre de Recherches sur les Macromolecules, \\ 67 Strasbourg, France.
}

(Received June 6, 1977)

\begin{abstract}
KEY WORDS Styrene-Isoprene-Styrene Copolymer / Morphology / Polarized Light Scattering / Stress-Strain Properties /
\end{abstract}

The mechanical properties of the three-block copolymers of the styrene-isoprene-styrene (SIS) type depend on their physical structure. The influence of morphology on these properties has been widely investigated, ${ }^{1-6}$ but so far the effect of the size of the morphological structures has not been taken into consideration.

Electron microscopic studies showed that polystyrene is SIS copolymer containing about $30 \%$ of styrene forms cylinders which aggregate into grains several microns long. ${ }^{7-10}$

In this paper some results concerning the relations between the size of these grains and the stressstrain properties of SIS copolymer ( $30 \%$ of styrene) prepared by the anionic copolymerization will be presented.

The samples were obtained by the evaporation of layers of $10-\%$ benzene solution of various thicknesses. Under these conditions the time of existence of the polymer in the swollen state, i.e., the time during which the degree of orderly arrangement of the polymer chains could increase, increased with increasing thickness of the solution layer. Evaporation was done at the normal temperature, first under the atmospheric and next under reduced pressure.

The differences between the sizes of the grains in the investigated samples were determined only qualitatively by small angle light scattering observations. $^{7,11,12}$ As a light source for SAIS ob-

\footnotetext{
* Present Address: Institute of Organic Chemistry and Technology, Technical University of Warsaw, Warsaw, Poland.
}

servations the $\mathrm{He}-\mathrm{Ne}$ laser was used. The $H_{\mathrm{v}}$ scattering patterns were obtained at the same distance between the sample and the photographic film (Figure 1). The $H_{\mathrm{v}}$ pattern of the sample obtained by evaporation of the thinnest layer of solution is shown in Figure 1a. In this case the grains are the smallest. Figures $1 \mathrm{~b}-\mathrm{d}$ show the $H_{\mathrm{v}}$ patterns of samples obtained by the evaporation of increasingly thick layers of solution. It can be seen from these pictures that the samples consist of larger and large grains.

The deformation of prepared samples was done at the normal temperature until the elongation rate $\lambda=1 / 1_{0}$ of about 3 was reached. The stressstrain relationships are shown graphically in Figure 2. The graphs show that the size of the grains has a pronounced effect on the mechanical proterties of the SIS copolymer. The greatest difference was observed between the sample consisting of the smallest grains (curve a) and the others (curves b-d).

From our results it is seen that not only the kind of structure but also the grain size has a significant effect on the mechanical properties of three-block copolymers.

\section{REFERENCES}

1. G. L. Wilkes and R. S. Stein, J. Polym. Sci., Part A-2, 7, 1525 (1969).

2. E. Fischer and J. F. Henderson, ibid., Part C, 26, 149 (1969).

3. M. Morton, J. E. McGrath, and P. C. Juliano, ibid., Part C, 26, 99 (1969).

4. T. L. Smith and R. A. Dickie, ibid., Part C, 26, 


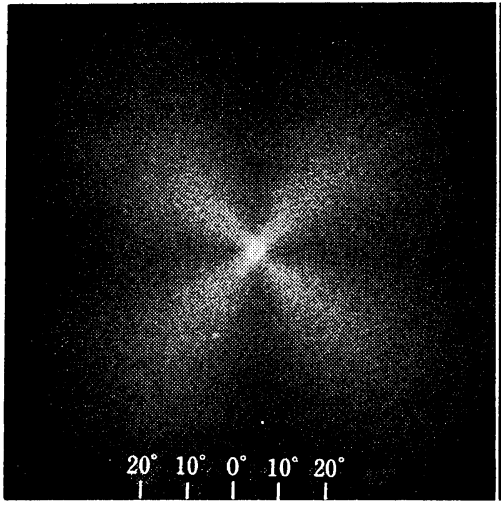

a

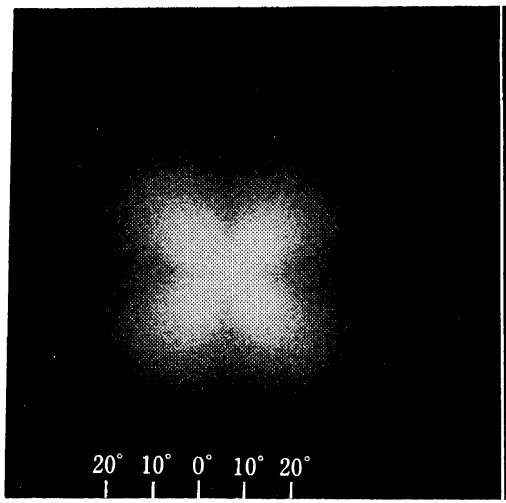

c

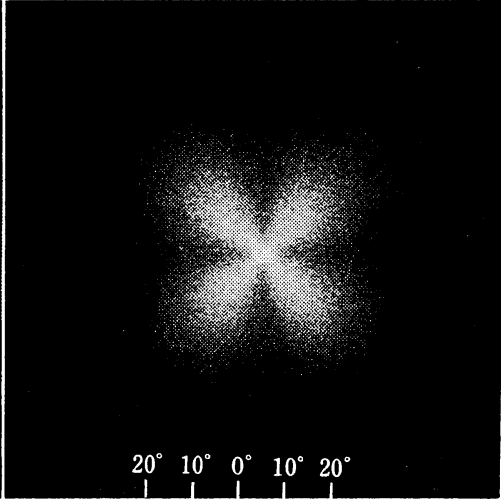

b

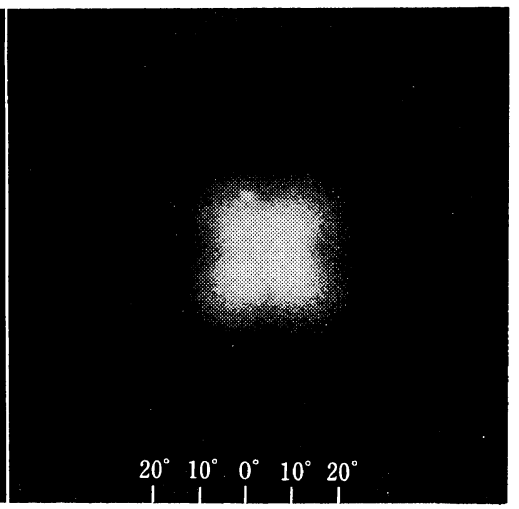

d

Figure 1. $H_{\mathrm{v}}$ scattering patterns of samples of SIS copolymer obtained by evaporation of increasingly thick layers of solution.

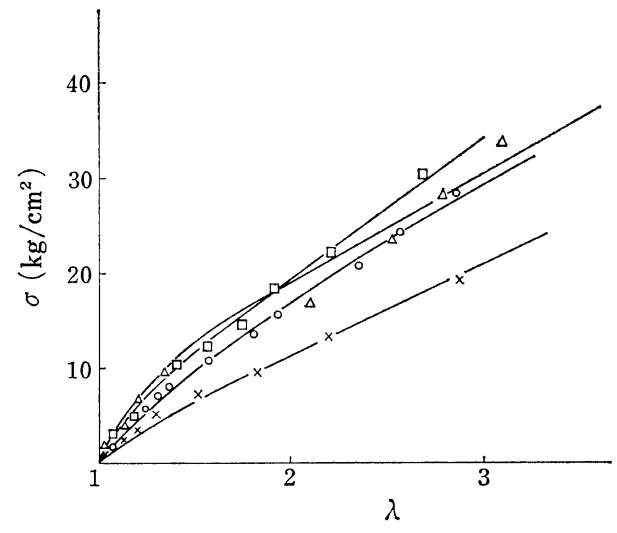

Figure 2. Stress-strain properties of a SIS samples consisting of grains of different sizes. The curves correspond to: $\times$, Figure $1 \mathrm{a} ; \mathrm{O}$, Figure $1 \mathrm{~b} ; \triangle$, Figure 1c; $\square$, Figure 1d. The thicknesses of the sample films were as follows: a, $0.1 \mathrm{~mm}$; b, $0.26 \mathrm{~mm}$;, $0.46 \mathrm{~mm}$; d, $0.57 \mathrm{~mm}$.
163 (1969).

5. E. Pedemonte, A. Turturro, and G. Dondero, Brit. Polym. J., 6, 277 (1974).

6. E. Pedemonte, G. Dondero, and G. C. Alfonso, Polymer 16, 531 (1975).

7. R. S. Stein, J. Polym. Sci., Part B, 9, 747 (1971).

8. E. Pedemonte, A. Turturro, U. Bianchi, and P. Devetta, Polymer., 14, 145 (1973).

9. E. B. Bradford and E. Vanzo, J. Polym. Sci., Part A-1, 6, 1661 (1968).

10. T. Inoue, T. Soen, H. Kawai, M. Fukatsu, and M. Kurata, ibid., Part B, 6, 75 (1968).

11. G. J. Wilkes, ibid., Part A-2, 10, 767 (1972).

12. I. Daniewska and C. Picot, Polym. J., 10, 141 (1978). 